Article

\title{
Enhanced Electrocatalytic Behaviour of Poy(aniline-co-2-hydroxyaniline) Coated Electrodes for Hydrogen Peroxide Electrooxidation
}

\author{
Anwar ul Haq Ali Shah ${ }^{1}$, Ayesha Inayat ${ }^{1}$ and Salma Bilal ${ }^{2,3, *}$ \\ 1 Institute of Chemical Sciences, University of Peshawar, Peshawar 25120, Pakistan \\ 2 National Centre of Excellence in Physical Chemistry, University of Peshawar, Peshawar 25120, Pakistan \\ 3 TU Braunschweig Institute of Energy and Process Systems Engineering, Franz-Liszt-Straße 35, \\ 38106 Braunschweig, Germany \\ * Correspondence: s.bilal@tu-braunschweig.de or salmabilal@uop.edu.pk; Tel.: +49-531-39163651 or \\ +92-919216766
}

Received: 25 June 2019; Accepted: 20 July 2019; Published: 24 July 2019

\begin{abstract}
Polymer-coated electrodes are widely used for the detection and oxidation of hydrogen peroxide $\left(\mathrm{H}_{2} \mathrm{O}_{2}\right)$. Conducting polyaniline (PANI), poly (2-hydroxyanilne) (PHA), and their copolymer poly(aniline-co-2-hydroxyaniline) (PACHA) were electrochemically synthesized on a gold substrate for $\mathrm{H}_{2} \mathrm{O}_{2}$ detection and analysis. Cyclic voltammetry (CV), square wave voltammetry (SWV), and differential pulse voltammetry (DPV) techniques were used for electroanalysis. Both PACHA and PANI greatly reduced the gold overpotential for $\mathrm{H}_{2} \mathrm{O}_{2}$ oxidation with enhanced current densities. The PACHA- and PANI-coated electrodes showed oxidative peaks at 0.30 and $0.50 \mathrm{~V}$, respectively, in the presence of $1.4 \times 10^{-6} \mathrm{M} \mathrm{H}_{2} \mathrm{O}_{2}$, while PHA-coated electrodes exhibited no response. The fabricated electrodes displayed a linear response towards $\mathrm{H}_{2} \mathrm{O}_{2}$ in range of $2 \times 10^{-7}$ to $1.4 \times 10^{-6} \mathrm{M}$, with very low detection limits (LODs) of $1 \times 10^{-7} \mathrm{M}$ (for PACHA) and $1.15 \times 10^{-7} \mathrm{M}$ (for PANI) evaluated from CV data. In case of SWV and DPV, the LODs were found to be $1.78 \times 10^{-7} \mathrm{M}$ (for PACHA) and $1 \times 10^{-7} \mathrm{M}$ (for PANI), respectively. The materials exhibit high sensitivity of $650 \mathrm{~A} / \mathrm{Mcm}^{2}$ and show good stability. The PACHA-coated electrode shows better capacitance $\left(1.84 \times 10^{-3} \mathrm{~F}\right)$ than PHA$\left(2.52 \times 10^{-4} \mathrm{~F}\right)$ and PANI-coated $\left(1.17 \times 10^{-3} \mathrm{~F}\right)$ electrodes.
\end{abstract}

Keywords: electrode fabrication; poly(aniline-co-2-hydroxyaniline); hydrogen peroxide; electroanalysis

\section{Introduction}

Hydrogen peroxide $\left(\mathrm{H}_{2} \mathrm{O}_{2}\right)$ has been of great value in biological systems and commercial applications, i.e., for bleaching, sterilizing, oxidizing, and for natural organic matter removal from water [1]. Though $\mathrm{H}_{2} \mathrm{O}_{2}$ is of great help, its excessive production and use can be hazardous, as it causes environmental pollution [2] $\mathrm{H}_{2} \mathrm{O}_{2}$ produced in mitochondria by oxidases, and is the main cause of various disorders like myocardial infarction, neurodegeneration, and Alzheimer's disease [3,4]. A high level of $\mathrm{H}_{2} \mathrm{O}_{2}$ is also toxic to cells, because it can disrupt its morphology and function $[5,6]$. Thus, detection and determination of $\mathrm{H}_{2} \mathrm{O}_{2}$ plays a vital role in many disciplines, like biochemistry, clinical, environmental chemistry, and pharmaceutical analysis.

In the recent few decades, many techniques, such as chromatography, fluorometry, spectrophotometry, and titrimetry, have been applied for the detection of $\mathrm{H}_{2} \mathrm{O}_{2}$. However, electrochemical techniques have gained more attention because of their high sensitivity, low cost, robust response, and easy operation. Many trials have shown that the reduction and oxidation of $\mathrm{H}_{2} \mathrm{O}_{2}$ occurring at solid electrodes displays the large overpotential and slow electrode dynamics, which has an adverse effect on detection performance, and also results in noisiness from other 
electroactive species in the practical determination of $\mathrm{H}_{2} \mathrm{O}_{2}$. Consequently, enzyme-involved biosensors have been used for the analysis of $\mathrm{H}_{2} \mathrm{O}_{2}$. Although the enzyme-modified electrodes show low detection limits, they have certain drawbacks like poor stability, a high cost of enzymes, and immobilization complexity. Fortunately, the emergence of coating electrodes with polymers opens a new doorway for $\mathrm{H}_{2} \mathrm{O}_{2}$ sensing, due to their greater stability and other properties, such as reducing overpotential, preventing electrode/electrode fouling, and interfering when the reagent solution is at a high concentration $[7,8]$. Polymers latch onto electrode surfaces, either by fixing the membranes (desired polymer membrane) that are available commercially or by electro-polymerization [9]. The latter method can be more useful than other methods because of its simplicity and the reproducibility of the construction process in a single step.

An electrode of the desired properties can be made by choosing an appropriate monomer and adequate experimental conditions. Thus, the thickness of the polymer membrane and other physical properties can be regulated by varying experimental conditions during the process of electro-polymerization. Electrodes modified with conducting polymers and nitrogen-doped graphene have been used for the oxidation of $\mathrm{H}_{2} \mathrm{O}_{2}$ [10], catechol [11], and ascorbic acid [12].

Conducting polymers are widely used for electrode surface coating, in order to enhance the bare electrode sensing properties. They have a large scope of applications in the realm of fuel cells [13], super capacitors [14], sensors [15], and electrocatalysis [16]. The most-used polymers are polyaniline (PANI), polypyrrole, polythiophene, and their derivatives. Due to its susceptibility and being easy to synthesize, PANI has attracted more attention. Some features of PANI can be upgraded via doping [17], interfacial polymerization, copolymerization, and the formation of bi-layer structures [18]. In addition, 2-hydroxyaniline, a derivative of aniline, contains hydroxyl and amino groups in its structural unit, and can be polymerized. The hydroxyl and amino groups in poly (2-hydroxyaniline) (PHA) can be oxidized and reduced electrochemically, and have been utilized in the fabrication of sensors [19].

A copolymer of aniline and 2-hydroxyaniline, poly (aniline-co-2-hydroxyaniline) (PACHA), with improved electrochemical properties both in neutral and basic media compared to its respective homopolymers, has been reported by our and other groups in the last decade [20,21]. Previous studies have shown that the anodic current response of PACHA is 1.3 times greater than PHA [22]. Furthermore, the electrochemical impedance spectroscopy revealed that the capacitance and conductivity of PACHA-coated electrodes increase by increasing the upper potential. The PACHA-modified electrode exhibits superior performance to PANI in the methanol oxidation reaction in direct methanol fuel cells (DMFCs). It is considered a good auxiliary material for the catalytic layer in DMFCs [22]. The copolymer is also used for the sensing of arsenate, uricase, and ascorbic acid [23]. It has been tested for probing radical scavengers of catechin and pyrogallol $[24,25]$. The fibers of PACHA were effectively used for the electro-oxidation of catechol in $\mathrm{Na}_{2} \mathrm{SO}_{4}$ solution [26].

In this work, we have tried to apply PACHA-coated electrode for the detection of $\mathrm{H}_{2} \mathrm{O}_{2}$ at a very minute level, by taking advantage of the redox behaviour of PACHA and comparing its electrocatalytic and capacitance properties with its homopolymers, as well as with previously reported data. The PACHA coating greatly reduces gold overpotential for $\mathrm{H}_{2} \mathrm{O}_{2}$ oxidation, even $200 \mathrm{mV}$ lower than a PANI coating, with enhanced anodic current density. The PACHA-modified electrode displayed a linear response towards $\mathrm{H}_{2} \mathrm{O}_{2}$ in the range of $2 \times 10^{-7}$ to $1.4 \times 10^{-6} \mathrm{M}$, with a very low detection limit (LOD) of $1 \times 10^{-7} \mathrm{M}$, and exhibited high sensitivity and good stability.

\section{Results and Discussion}

\subsection{Cyclic Voltammetry Analysis}

Figure 1 shows the cyclic voltammograms of bare gold electrodes, as well as PACHA-, PANI-, and PHA-coated electrodes in $0.1 \mathrm{M}$ sodium citrate solution, with and without $\mathrm{H}_{2} \mathrm{O}_{2}$. 

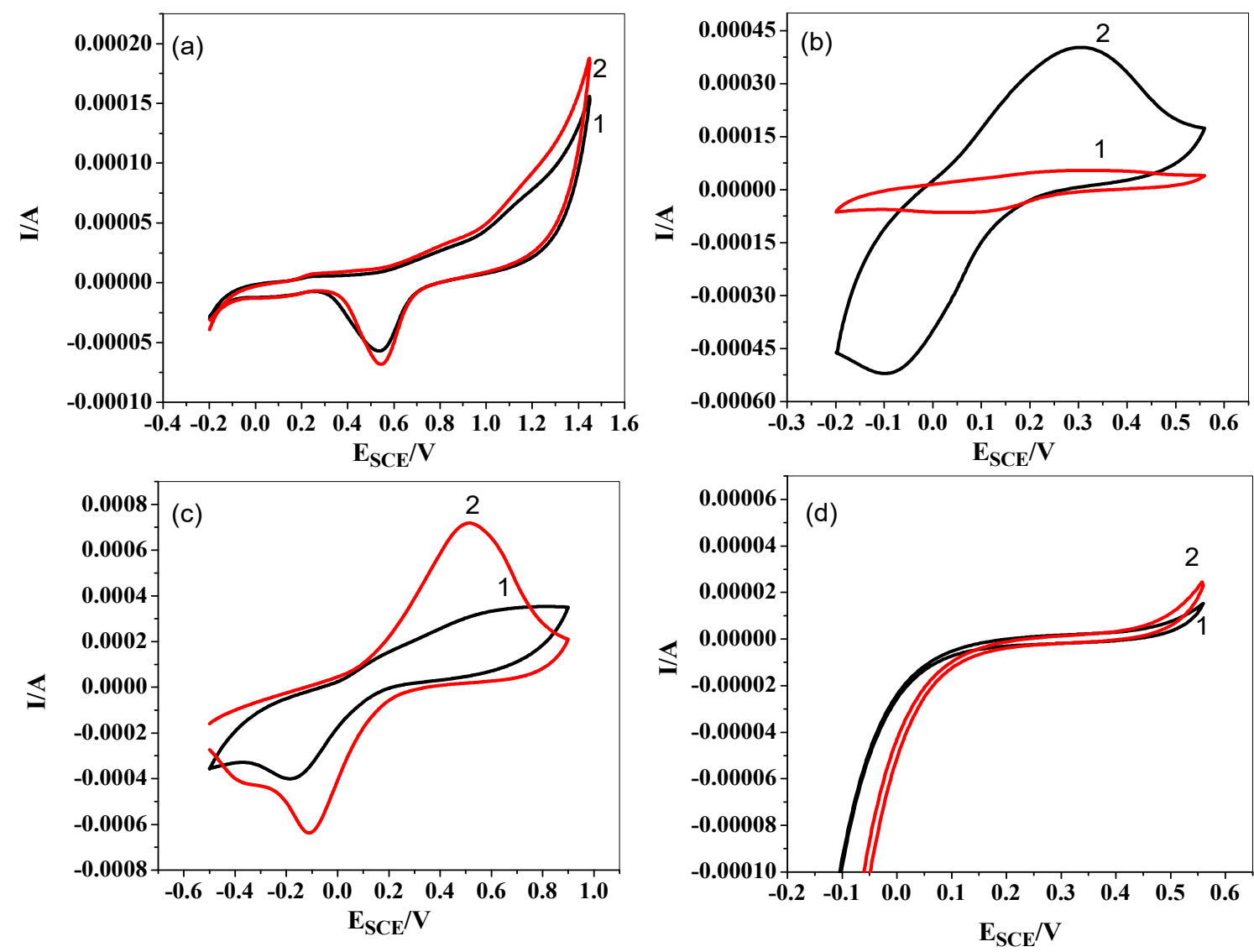

Figure 1. Cyclic voltammetry (CV) of (a) bare gold, (b) poly(aniline-co-2-hydroxyaniline) (PACHA)-, (c) polyaniline (PANI)-, and (d) poly (2-hydroxyanilne) (PHA)-coated electrodes in a citrate buffer of $\mathrm{pH}$, without (1) and with (2) $1.4 \times 10^{-6} \mathrm{M} \mathrm{H}_{2} \mathrm{O}_{2}$.

It can be perceived from Figure 1 a that bare gold electrodes show a very small current response towards $\mathrm{H}_{2} \mathrm{O}_{2}$ at large oxidation potential. In Figure $1 \mathrm{~b}$, the copolymer displays a couple of electrochemical responses because of the redox nature of the copolymer. The anodic and cathodic peaks are observed at $0.32 \mathrm{~V}$ and $0.03 \mathrm{~V}$, respectively, while after the addition of $\mathrm{H}_{2} \mathrm{O}_{2}$ the anodic and cathodic peaks shift to $0.30 \mathrm{~V}$ and $-0.10 \mathrm{~V}$. The curve also shows great increase in current peaks by the addition of $\mathrm{H}_{2} \mathrm{O}_{2}$. As shown in Figure 1c, the case of PANI is similar. PANI exhibits good electrochemical response towards $\mathrm{H}_{2} \mathrm{O}_{2}$. The anodic and cathodic peaks are observed at $0.75 \mathrm{~V}$ and $-0.18 \mathrm{~V}$, but after the addition of $\mathrm{H}_{2} \mathrm{O}_{2}$ the peaks shift to $0.50 \mathrm{~V}$ and $-0.11 \mathrm{~V}$, respectively. An increase in current peaks is also observed when $\mathrm{H}_{2} \mathrm{O}_{2}$ is added. From Figure 1, it is evident that both PANI and PACHA possess effectual electrochemical responses towards $\mathrm{H}_{2} \mathrm{O}_{2}$, offering a way to be used as $\mathrm{H}_{2} \mathrm{O}_{2}$ sensors. Based on the quantity of anodic peak currents, PANI is more electro-active towards $\mathrm{H}_{2} \mathrm{O}_{2}$ than PACHA. A possible reason might be the large separation of the polymer chain by side groups in the copolymer [21]. Interestingly, the $\mathrm{H}_{2} \mathrm{O}_{2}$ oxidation peak was observed at $0.30 \mathrm{~V}$ on the PACHA-coated electrodes. This potential was lower by $0.21 \mathrm{~V}$ compared to the $\mathrm{H}_{2} \mathrm{O}_{2}$ oxidation peak observed for the PANI-coated electrodes. This finding shows that the overpotential for $\mathrm{H}_{2} \mathrm{O}_{2}$ oxidation is greatly increased when the PACHA-coated electrode was used, indicating that the coating is favorable for $\mathrm{H}_{2} \mathrm{O}_{2}$ detection purposes. The PACHA detects $\mathrm{H}_{2} \mathrm{O}_{2}$ at a lower potential, not only with respect to PANI [26], but also poly(aniline-co-p-aminophenol) [27] and poly(thiophene-2-aminophenol-3-thiopheneacetic acid) [28]. The current response of $\mathrm{PHA}$ towards $\mathrm{H}_{2} \mathrm{O}_{2}$ is almost negligible compared to the response of PACHA and PANI; this might be due to the compact structural morphology and lower conductivity of PHA, as PHA is a redox polymer, having a ladder-like structure in which the electron transfer takes place by a hopping process, as there is no continuous path for the electron flow; thus, the conduction 
of the polymer is reduced. The inconsequential response of PHA towards $\mathrm{H}_{2} \mathrm{O}_{2}$ analysis may also be attributed to the $\mathrm{pH}$ of the solution in which the experiment is carried out, because the electrochemical activity of PHA quietly decreases in buffer solution of neutral $\mathrm{pH}$.

\subsubsection{Scan Rate and Rate Constant Analysis}

The electrochemical response of PANI- and PACHA-coated electrodes towards $\mathrm{H}_{2} \mathrm{O}_{2}$ was checked both at lower and higher scan rates. A total of $1.4 \times 10^{-6} \mathrm{M}$ of $\mathrm{H}_{2} \mathrm{O}_{2}$ was taken for the purpose. It can be seen from Figure 2 that the current peak increases linearly with the square root of the scan rate $(v 1 / 2)$ for $\mathrm{H}_{2} \mathrm{O}_{2}$, thus indicating that the redox reaction of $\mathrm{H}_{2} \mathrm{O}_{2}$ on the surface of PANI- and PACHA-coated electrodes is a diffusion-controlled process.
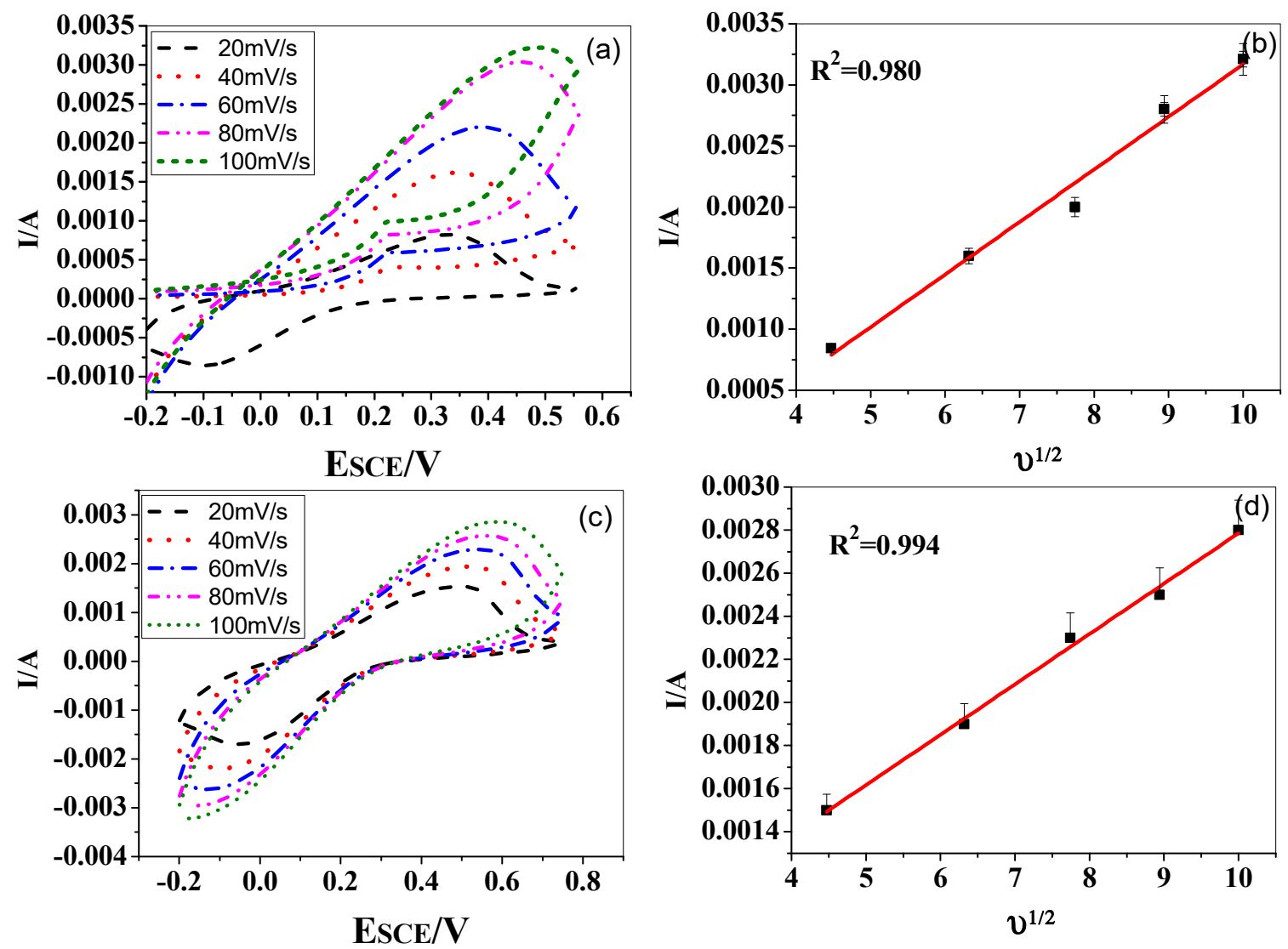

Figure 2. $\mathrm{CV}$ of (a) PACHA (c) PANI at different scan rates in $1.4 \times 10^{-6} \mathrm{M} \mathrm{H}_{2} \mathrm{O}_{2} ;(\mathbf{b}$,d) the dependence of the anodic peak current on the square root of scan rates.

For a redox couple having an intermediate electron transfer rate constant, the anodic peak current $\left(\mathrm{I}_{p a}\right)$ and scan rate $(v)$ can be related by Equation (1):

$$
I_{p a}=0.496 n F A C D^{\frac{1}{2}}\left(\frac{\left(\alpha n_{\alpha}\right) F v}{R T}\right)^{\frac{1}{2}}
$$

where $F$ is the Faraday constant, $A$ is the area of electrode, $C$ is concentration, $D$ is the diffusion coefficient (in $\mathrm{cm}^{2} \mathrm{~s}^{-1}$ ), $\alpha$ is the charge transfer coefficient, $R$ is universal gas constant, $T$ is the absolute temperature, and $n_{\alpha}$ is the number of electrons transferred in a reaction. The $\alpha n_{\alpha}$ can be calculated from Equation (2):

$$
\left|E_{p a}-E_{p a / 2}\right|=1.857 R T / F \alpha n_{\alpha}
$$


where $E_{p a}$ is the anodic peak potential and $E_{p a / 2}$ is the half-peak potential. By substituting the $\alpha n_{\alpha}$ value in Equation (1), the diffusion coefficient ca be estimated. The $k_{s}$ (rate constant for a charge transfer reaction) value for a quasi-reversible redox reaction can also be resolute from Equation (3):

$$
k_{s}=2.18\left[D\left(\alpha n_{\alpha}\right) v F / R T\right]^{\frac{1}{2}} \exp \left[\alpha^{2} n F\left(E_{p c}-E_{p a}\right) / R T\right]
$$

The resulting $\alpha n_{\alpha}$ values for $\mathrm{H}_{2} \mathrm{O}_{2}$ at the scan rate of $0.05 \mathrm{Vs}^{-1}$ for PANI- and PACHA-coated electrodes are 0.20 and 0.25 , respectively. The diffusion coefficient of PANI was found to be $6.9 \mathrm{~cm}^{2} \mathrm{~s}^{-1}$, which is more than PACHA $\left(3.47 \mathrm{~cm}^{2} \mathrm{~s}^{-1}\right)$, meaning that $\mathrm{H}_{2} \mathrm{O}_{2}$ diffuses faster into PANI than PACHA. The $k_{s}$ value for PANI is $3.42 \times 10^{-1} \mathrm{~cm} \mathrm{~s}^{-1}$, while for PACHA it decreases to $2.83 \times 10^{-1} \mathrm{~cm} \mathrm{~s}^{-1}$; the reason for this may be that the charge transfer between the PANI and $\mathrm{H}_{2} \mathrm{O}_{2}$ takes place at a faster rate.

\subsubsection{Electrochemical Response with an Increase in Concentration}

Figure 3 shows cyclic voltammograms of PACHA- and PANI-coated electrodes in different concentrations of $\mathrm{H}_{2} \mathrm{O}_{2}$. It is observed that the oxidation peak constantly increases with the increase in $\mathrm{H}_{2} \mathrm{O}_{2}$ concentration, which means that the current peak has a direct and linear relation with $\mathrm{H}_{2} \mathrm{O}_{2}$ concentration [29].
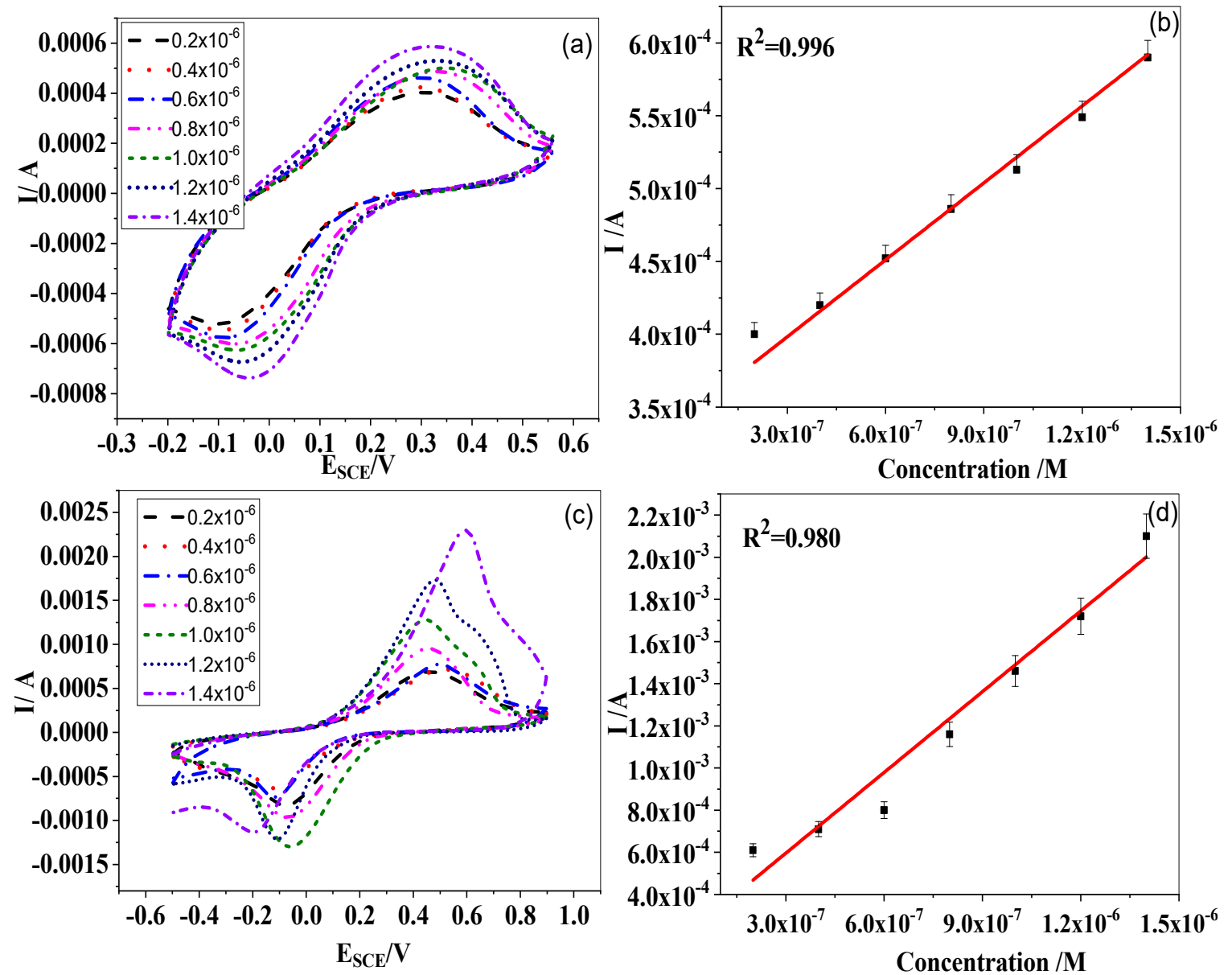

Figure 3. $\mathrm{CV}$ of (a) PACHA and (c) PANI at different concentrations of $\mathrm{H}_{2} \mathrm{O}_{2} ;(\mathbf{b}, \mathbf{d})$ show the calibration curve of PACHA and PANI with $\mathrm{H}_{2} \mathrm{O}_{2}$ concentrations ranging from $2 \times 10^{-7}$ to $4 \times 10^{-6} \mathrm{M}$.

The calibration curves obtained are shown in Figure $3 \mathrm{~b}$,d. The coefficient $\left(R^{2}\right)$ values attained from the linear calibration curve of $\mathrm{H}_{2} \mathrm{O}_{2}$ concentration ranging from $2 \times 10^{-7}$ to $14 \times 10^{-7} \mathrm{M}$ at PACHA and 
PANI coated electrodes were 0.996 and 0.980 , respectively. The limit of detection (LOD) was calculated with the help of following equation [30]:

$$
\mathrm{LOD}=3 \sigma / m
$$

where $\sigma$ stands for the standard deviation of the blank/regression line, and $m$ is the slope of the calibration line. The limit of detection and limit of quantification calculated were found to be $1 \times 10^{-7} \mathrm{M}$, and $3.3 \times 10^{-7} \mathrm{M}$ for PACHA, while for PANI they increase to $1.15 \times 10^{-7} \mathrm{M}$ and $3.8 \times 10^{-7} \mathrm{M}$, respectively.

\subsection{Square Wave Voltammetry Analysis}

Square wave voltammetry (SWV) and Differential Pulse Voltammetry (DPV) were also employed to scrutinize the oxidation of $\mathrm{H}_{2} \mathrm{O}_{2}$ on PACHA-, PANI-, and PHA-coated gold electrodes, because of their high current sensitivity and low contribution to the background current.

Figure 4 shows the square wave voltammograms of bare as well as PHA-, PANI-, and PACHA-coated gold electrodes in $0.1 \mathrm{M}$ acetate buffer containing $14 \times 10^{-7} \mathrm{M} \mathrm{H}_{2} \mathrm{O}_{2}$. Oxidation peaks were obtained, and the peak potential and the current at different electrodes are quite indistinguishable. The anodic peaks at bare and PHA-coated electrodes were at $-0.60 \mathrm{~V}$ and $-0.07 \mathrm{~V}$, respectively, with a very small peak current.
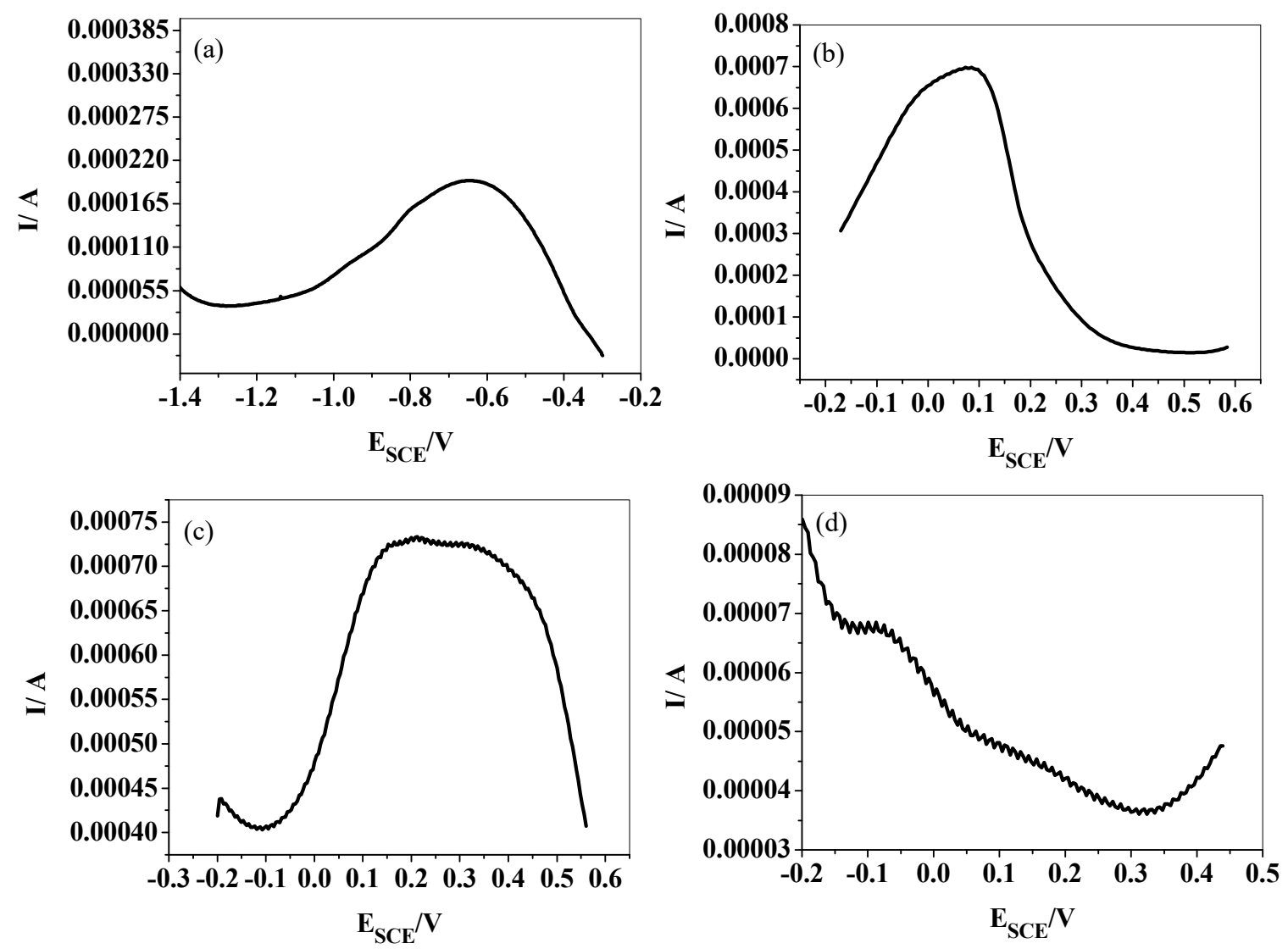

Figure 4. Square wave voltammograms of (a) bare, as well as (b) PACHA-, (c) PANI-, and (d) PHA-coated electrodes in citrate buffer of $\mathrm{pH} 5$, containing $1.4 \times 10^{-6} \mathrm{M} \mathrm{H}_{2} \mathrm{O}_{2}$.

The oxidation of $\mathrm{H}_{2} \mathrm{O}_{2}$ by a PACHA-coated electrode gives rise to a single peak at $0.08 \mathrm{~V}$, while PANI results at $0.20 \mathrm{~V}$. The peak current in the case of PANI is greater than PACHA; however, the voltammetry peak for a PANI-coated electrode is broader, which makes the determination of individual concentration complicated [31]. PACHA resolved the merged anodic peaks in distinct 
voltammetry peaks. From the peak current analysis, it is clear that PACHA- and PANI-coated electrodes enhance the electrochemical response towards $\mathrm{H}_{2} \mathrm{O}_{2}$. The SWV results are in good agreement with the $\mathrm{CV}$ results.

Electrochemical Response with an Increase in Concentration

Figure 5 shows SWV voltammograms of PACHA and PANI in different concentration of $\mathrm{H}_{2} \mathrm{O}_{2}$. It can be observed that the current peak increases with the increase in $\mathrm{H}_{2} \mathrm{O}_{2}$ concentration. The calibration curve obtained is shown in the inset. The coefficient $\left(R^{2}\right)$ value obtained from the linear calibration curve of the $\mathrm{H}_{2} \mathrm{O}_{2}$ concentration at PACHA was 0.944 . The limit of detection and limit of quantification calculated were found to be $1.78 \times 10^{-7} \mathrm{M}$ and $5.6 \times 10^{-7} \mathrm{M}$ for PACHA, respectively, while for PANI they cannot be evaluated due to the broader current peaks.
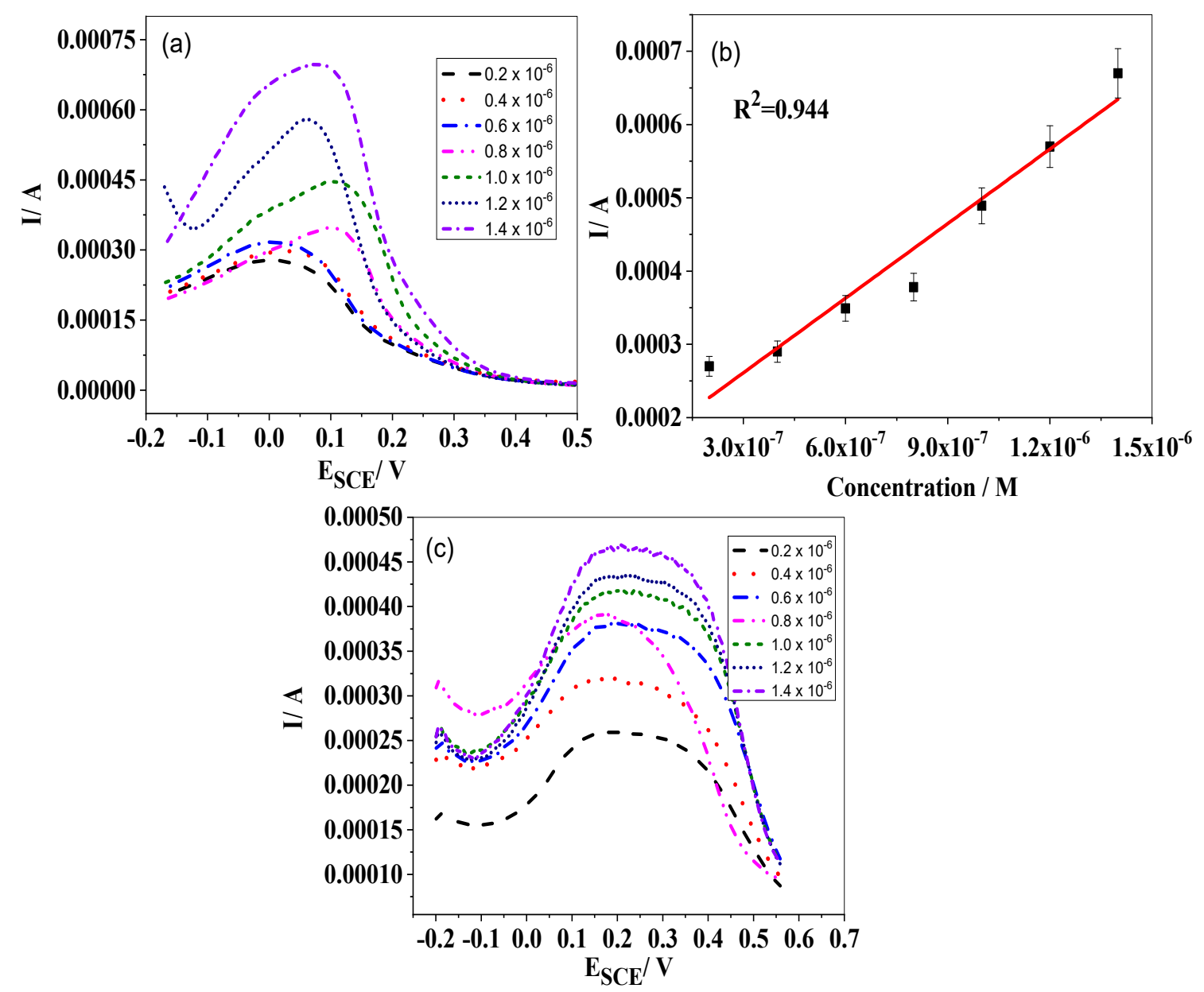

Figure 5. Square wave voltammograms of (a) PACHA and (c) PANI at different levels of $\mathrm{H}_{2} \mathrm{O}_{2}$ concentration; (b) shows the response curve of PACHA with $\mathrm{H}_{2} \mathrm{O}_{2}$ concentration ranges from $2 \times 10^{-7}$ to $1.4 \times 10^{-6} \mathrm{M}$.

\subsection{Differential Pulse Voltammetry Analysis}

Differential pulse voltammograms (DPVs) of $\mathrm{H}_{2} \mathrm{O}_{2}$ for PACHA-, PANI-, and PHA-coated as well as bare electrodes are shown in Figure 6.

The oxidation peak of $\mathrm{H}_{2} \mathrm{O}_{2}$ for the PANI- and PACHA-coated electrodes are observed at $0.20 \mathrm{~V}$ and $0.10 \mathrm{~V}$, respectively. It can be seen that the oxidation peak currents of $\mathrm{H}_{2} \mathrm{O}_{2}$ for the PACHA- and PANI-coated electrodes are much higher than the bare and PHA-coated electrodes. Similar to CV and SWV, the DPV results show that the oxidation of $\mathrm{H}_{2} \mathrm{O}_{2}$ takes place at a higher potential with 
PANI-coated electrodes compared to PACHA-coated electrodes. The DPV data are in agreement with the CV and SWV data. However, the current response in the case of SWV is greater than that of CV and DPV. This may be because of the efficient elimination of capacitance current [32].
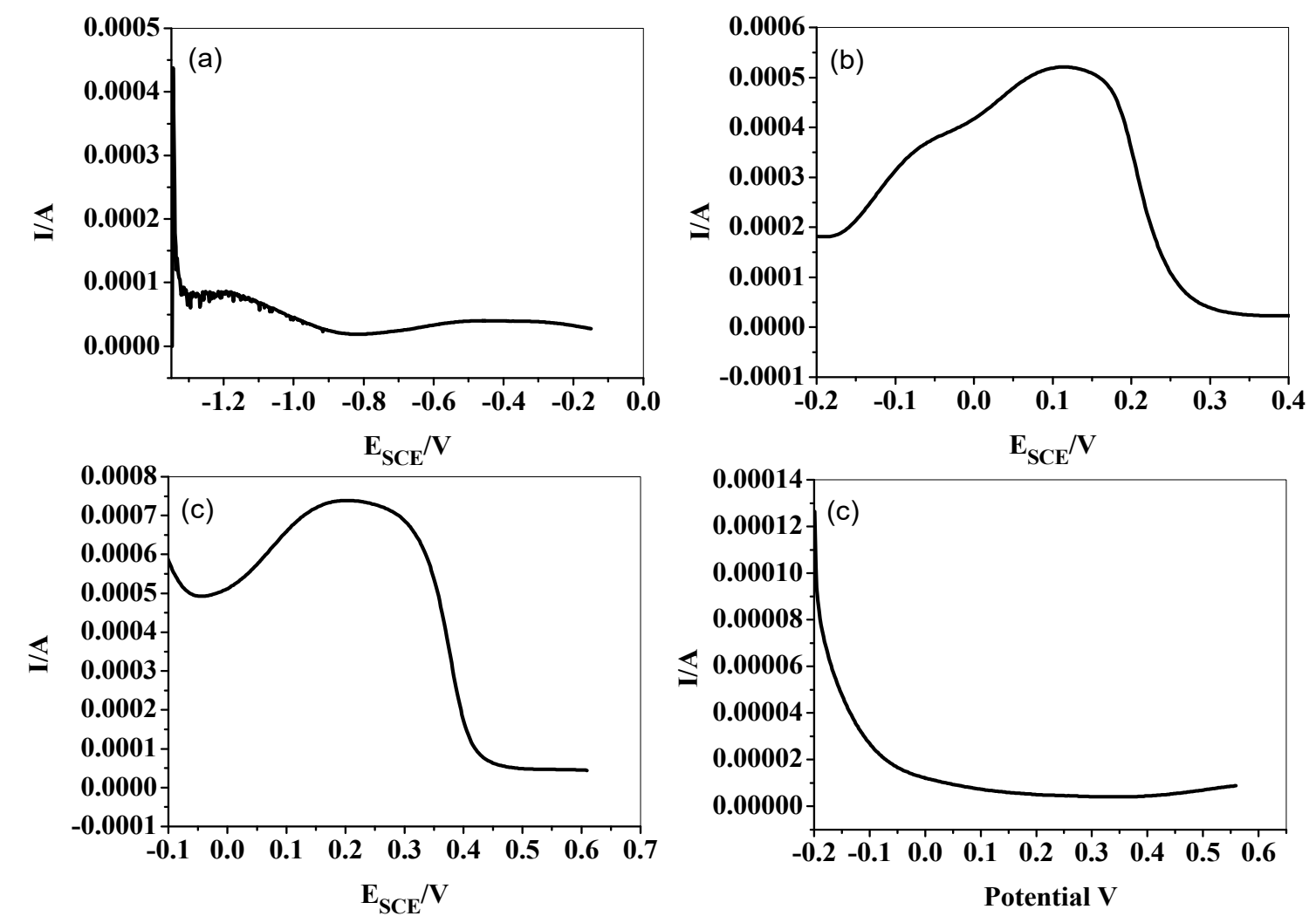

Figure 6. Differential pulse voltammograms (DPVs) of (a) bare as well as (b) PACHA-, (c) PANI-, and (d) PHA-coated electrodes in citrate buffer ( $\mathrm{pH}$ 5) containing $1.4 \times 10^{-6} \mathrm{M} \mathrm{H}_{2} \mathrm{O}_{2}$ solution.

Electrochemical Response with Increase in Concentration

DPVs of PACHA and PANI in different concentrations of $\mathrm{H}_{2} \mathrm{O}_{2}$ are given in Figure 7. Figure $7 \mathrm{~b}, \mathrm{~d}$ shows the calibration curve with coefficient $R^{2}$ values of 0.963 for PANI and 0.971 for PACHA. A direct relationship between current peak and $\mathrm{H}_{2} \mathrm{O}_{2}$ concentration is attained. The curves also show a peak shift with the increase of $\mathrm{H}_{2} \mathrm{O}_{2}$ concentration; the reason for this may be that a high voltage is required for the electrons to surpass the interface [33]. The limit of detection (LOD) and limit of quantification (LOQ) obtained were $1 \times 10^{-7} \mathrm{M}$ and $3.3 \times 10^{-7} \mathrm{M}$, respectively, for both PANI- and PACHA-coated electrodes. The DPV results validate the $\mathrm{CV}$ and SWV data.

The LOD of $\mathrm{H}_{2} \mathrm{O}_{2}$ is given in Table 1. It can be seen from Table 1 that the LODs obtained from different techniques are quite comparable with each other, and are much lower than the already reported data [34-37]. It can be concluded from these results that electrodeposited PACHA and PANI on the surface of an Au electrode enables the detection of $\mathrm{H}_{2} \mathrm{O}_{2}$ at a low concentration level. The LOD and LOQ determined with a DPV have the same values both for PANI- and PACHA-coated electrodes, despite the higher peak current of PANI compared to PACHA. The DPV curves of PANI do not show sharp peaks, but rather wide current plateaus spreading over the region from 50 to $200 \mathrm{mV}$. The DPV curves of PACHA show sharp peaks around $50 \mathrm{mV}$; however, the current peaks shift towards $100 \mathrm{mV}$ with the increase in concentration of ascorbic acid (AA). The LOD and LOQ values evaluated from DPV curves depend not only on the peak current, but also the linearity and slope of the calibration curve. The $R^{2}$ value of PACHA (Figure $7 \mathrm{~b}$ ) is higher than for PANI (Figure 7d); therefore, the LOD and LOQ values determined with a PACHA-coated electrode resemble those determined with a PANI-coated electrode. 

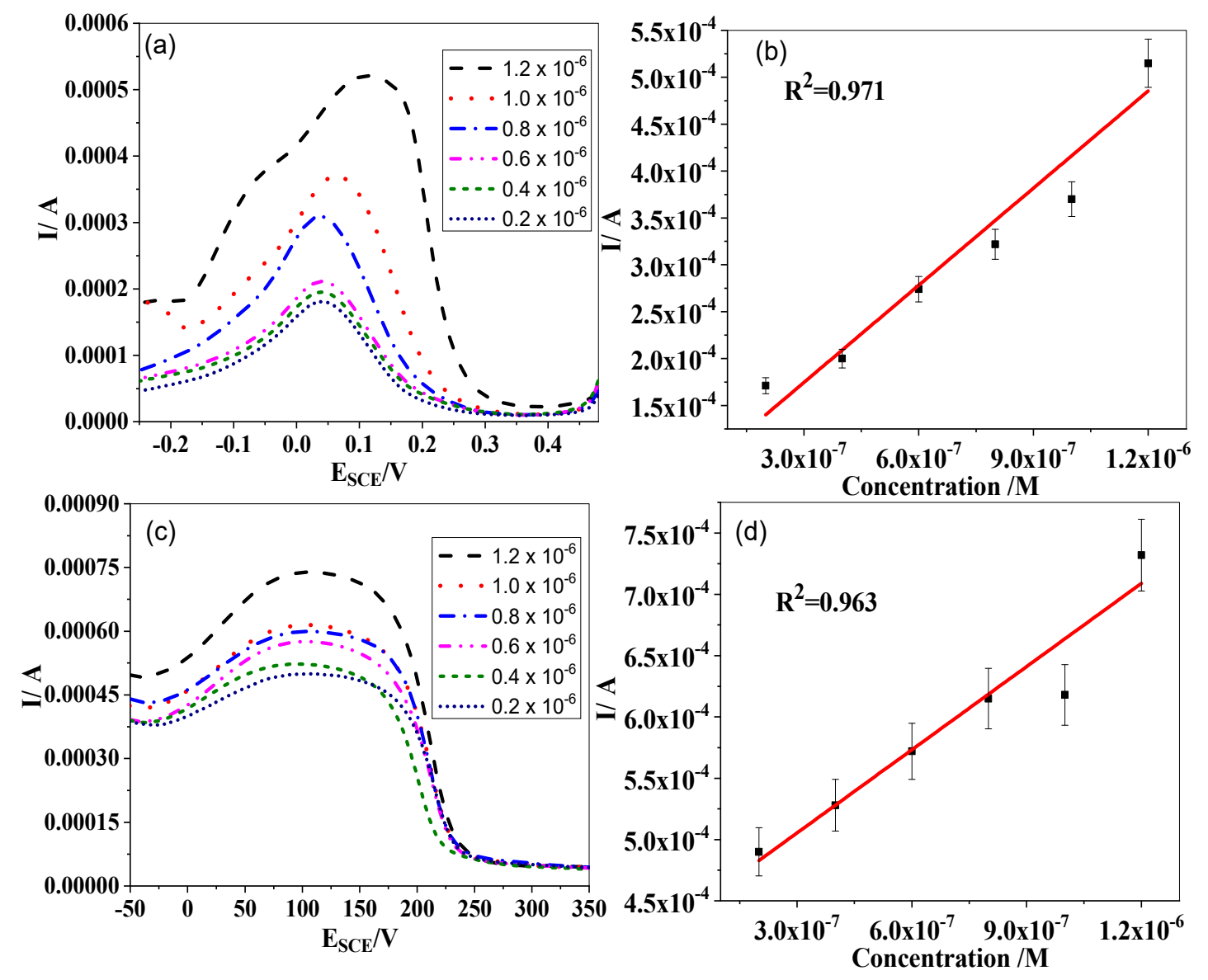

Figure 7. DPVs of (a) PACHA and (c) PANI at different $\mathrm{H}_{2} \mathrm{O}_{2}$ concentrations; (b) and (d) display the current response of PACHA and PANI, respectively, with $\mathrm{H}_{2} \mathrm{O}_{2}$ concentration ranging from $2 \times 10^{-7}-1.2 \times 10^{-6} \mathrm{M}$.

Table 1. Comparison of various characteristics of PANI and PACHA along with the reported data.

\begin{tabular}{|c|c|c|c|c|c|}
\hline Electrode Technique & $\begin{array}{l}\text { Detection } \\
\text { Potential }\end{array}$ & Linearity (M) & LOD (M) & LOQ (M) & $\begin{array}{l}\text { Sensitivity } \\
\mathrm{A} / \mathrm{Mcm}^{2}\end{array}$ \\
\hline PACHA-Au, CV & $0.3 \mathrm{~V}$ & $2 \times 10^{-7}-1.4 \times 10^{-6}$ & $1 \times 10^{-7}$ & $3.3 \times 10^{-7}$ & \\
\hline PANI-Au, CV & $0.5 \mathrm{~V}$ & $2 \times 10^{-7}-1.4 \times 10^{-6}$ & $1.15 \times 10^{-7}$ & $3.8 \times 10^{-7}$ & \\
\hline PACHA-Au, SWV & $0.08 \mathrm{~V}$ & $2 \times 10^{-7}-1.4 \times 10^{-6}$ & $1.78 \times 10^{-7}$ & $5.6 \times 10^{-7}$ & \\
\hline PACHA-Au, DPV & $0.1 \mathrm{~V}$ & $2 \times 10^{-7}-1.4 \times 10^{-6}$ & $1 \times 10^{-7}$ & $3.3 \times 10^{-7}$ & 650 \\
\hline PANI-Au, DPV & $0.20 \mathrm{~V}$ & $2 \times 10^{-7}-1.4 \times 10^{-6}$ & $1 \times 10^{-7}$ & $3.3 \times 10^{-7}$ & 434 \\
\hline rGO-Nf@Ag6 & & & $5.35 \times 10^{-7}[34]$ & & \\
\hline $\begin{array}{c}\text { Silicon/silver } \\
\text { nanocomposite }\end{array}$ & & $1.65 \times 10^{-6}-0.5 \times 10^{-3}$ & $0.45 \times 10^{-6}[35]$ & & \\
\hline $\mathrm{Au} /$ graphene/HRP/CS & & & $1.7 \times 10^{-6}[36]$ & & \\
\hline MWCNT-graphene & & $20 \times 10^{-6}-2.1 \times 10^{-3}$ & $9.4 \times 10^{-6}[36]$ & & \\
\hline BGNs & & $1 \times 10^{-3}-20 \times 10^{-3}$ & $3.8 \times 10^{-6}[36]$ & & $\begin{array}{c}266.7 \times 10^{-6} \\
{[36]}\end{array}$ \\
\hline Ag NS/ITO & & $0.2 \times 10^{-3}-4 \times 10^{-3}$ & $1 \times 10^{-6}[37]$ & & \\
\hline Graphene-hAuPd & & $0.1 \times 10^{-6}-20 \times 10^{-6}$ & & & $5.059[36]$ \\
\hline RGO-MWCNT-Pt/Mb & & & & & $1.99 \times 10^{-6}[36]$ \\
\hline
\end{tabular}




\subsection{Stability, Sensitivity, and Reproducibility}

The stability of the electrodes was determined by keeping the electrodes in $1 \mathrm{M}$ solution of citrate buffer ( $\mathrm{pH}$ ) for 10 days and recording $\mathrm{CV}$ before and after immersion in $1.4 \times 10^{-6} \mathrm{M} \mathrm{H}_{2} \mathrm{O}_{2}$ solution. The resulted CV graph is provided in Figure $\mathrm{S} 1$ of the supporting file. The results show that the current peak decreased very slightly for the PACHA-coated electrode, indicating its good stability. DPV measurements were carried out in order to analyze the sensitivity of the sensors. The resulted data was plotted as a calibration curve of current versus concentration in Figure S2. The sensitivity of electrodes was evaluated using Equation (5) [38]:

$$
\text { Sensitivity }=\frac{m}{A}
$$

In the above equation, $m$ is the slope of calibration curve and $A$ is the area of active sites of electrode, where $A=0.5 \mathrm{~cm}^{2}$. The resulted sensitivity value for PACHA was $650 \mathrm{~A} / \mathrm{Mcm}^{2}$ in terms of current, while for PANI it was $434 \mathrm{~A} / \mathrm{Mcm}^{2}$. The sensitivity was found to be much greater than previously reported $\mathrm{H}_{2} \mathrm{O}_{2}$ sensors [36,39]. The current values assure the high sensitivity of both PACHA- and PANI-coated electrodes. The reproducibility of the sensor was also scrutinized with the help of cyclic voltammetry. The electrochemical behavior of PACHA was noted in solutions of different concentrations. The derived data was reported in Figure S3 in the form of a calibration curve. The LOD calculated from the reproducibility measurement was $1 \times 10^{-7}$, which is same as the LOD reported earlier, thus assuring the repeatability of the PACHA-coated electrode.

\subsection{Electrochemical Impedance Measurements}

Electrochemical impedance spectroscopy (EIS) is considered to be a promising tool for interfacial properties studies of surface modified electrodes. The data is usually presented in the form of Nyquist and Bode plots. The diameter of the semicircle in a Nyquist plot represents the charge transfer resistance (Rct), and the straight line shows the diffusion-related process [40]. Figure 8 shows Nyquist plots of bare gold and polymer-coated electrodes in citrate buffer ( $\mathrm{pH}$ 5) containing $1.4 \times 10^{-6} \mathrm{M} \mathrm{H}_{2} \mathrm{O}_{2}$ solution. As can be easily observed, PACHA exhibits both a semicircle and a straight line. However, the semicircle diameter is very small, suggesting low Rct to the $\mathrm{H}_{2} \mathrm{O}_{2}$ dissolved in the citrate buffer solution. The Nyquist plots of bare $\mathrm{Au}$ and PANI-coated electrodes indicate that the impedance is due to the interfacial charge transfer within the applied frequency range [41]. However, the PHA shows only a diffusional, limited electrochemical process [42].

The Bode plot of capacitance versus frequency, obtained with PANI-, PACHA-, PHA-coated electrodes, is given in Figure 9a. It is clear from the figure that the capacitance decreases with the increase in frequency. However, the lowering of the capacitance value is only observed in the low frequency range, whereas the ion permeability of the films remains the same at the higher frequency range. The resulted capacitance values of PACHA-Au, PANI-Au, PHA-Au, and Au were $1.84 \times 10^{-3} \mathrm{~F}$, $1.17 \times 10^{-3} \mathrm{~F}, 2.52 \times 10^{-4} \mathrm{~F}$, and $1.21 \times 10^{-2} \mathrm{~F}$, respectively. The capacitance of PACHA is greater than its homopolymers, which means that PACHA is more permeable and has a higher tendency for charge storage than PANI and PHA.

The phase angle decreases in order of PHA > PANI > Au > PACHA, as shown in Figure 9b. The decrease in phase angle specifies the reduction in inductive parameters like charge transfer resistance, membrane resistance, and solution resistance [43]. The decrease in phase angle also enhances the inductive behavior of the electrode. A capacitor with promising inductive behavior requires a low phase angle. It can be seen in Figure $9 \mathrm{~b}$ that $\mathrm{Au}$ and PACHA exhibit low phase angles; hence, it is assumed that their inductive properties are better than both the homo-polymers. The phase angle analysis is in agreement with capacitance. 

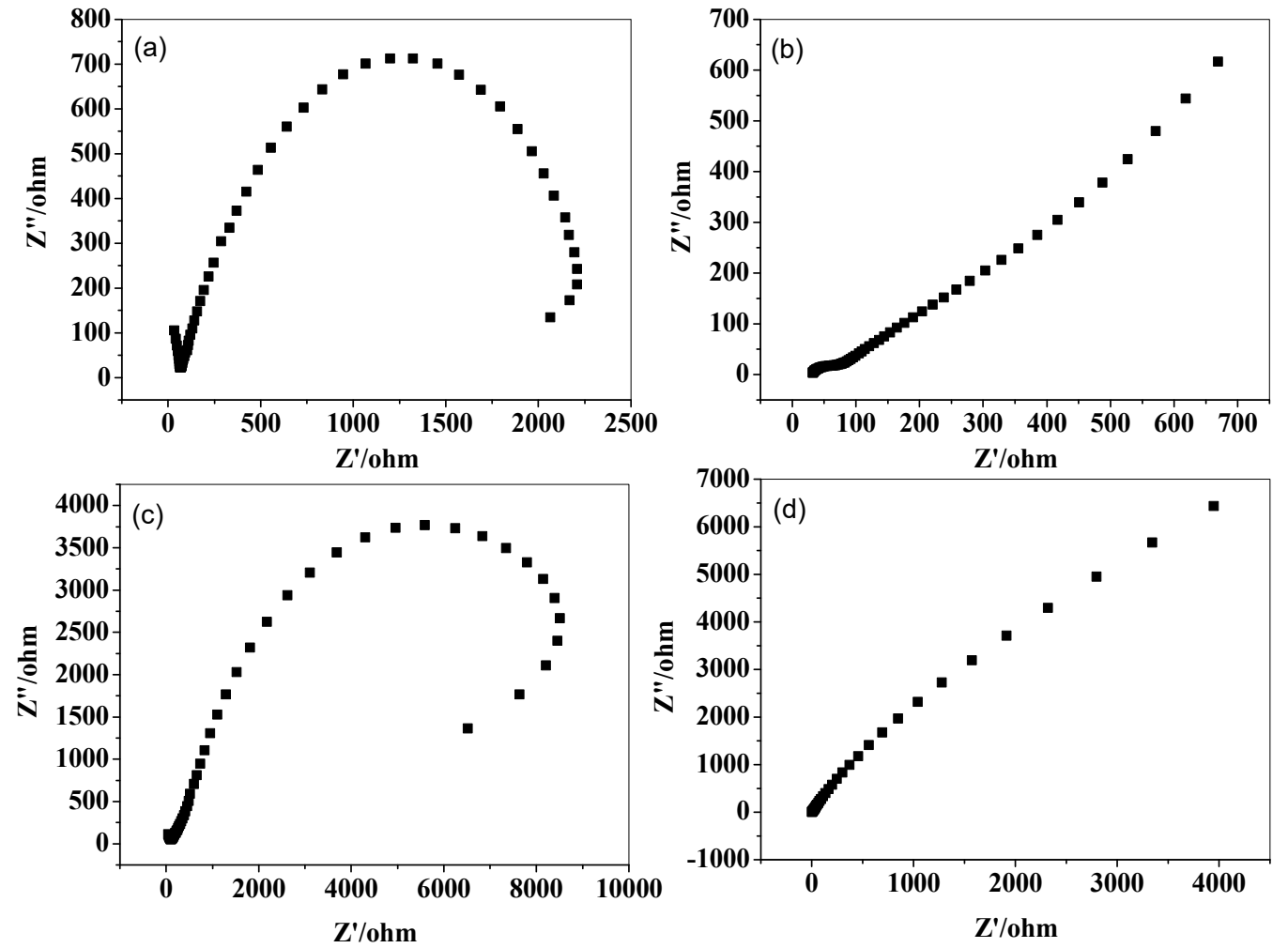

Figure 8. Nyquist plot of (a) Au, (b) PACHA, (c) PANI, and (d) PHA in citrate buffer (pH 5) and $1.4 \times 10^{-6} \mathrm{M} \mathrm{H}_{2} \mathrm{O}_{2}$ solution.
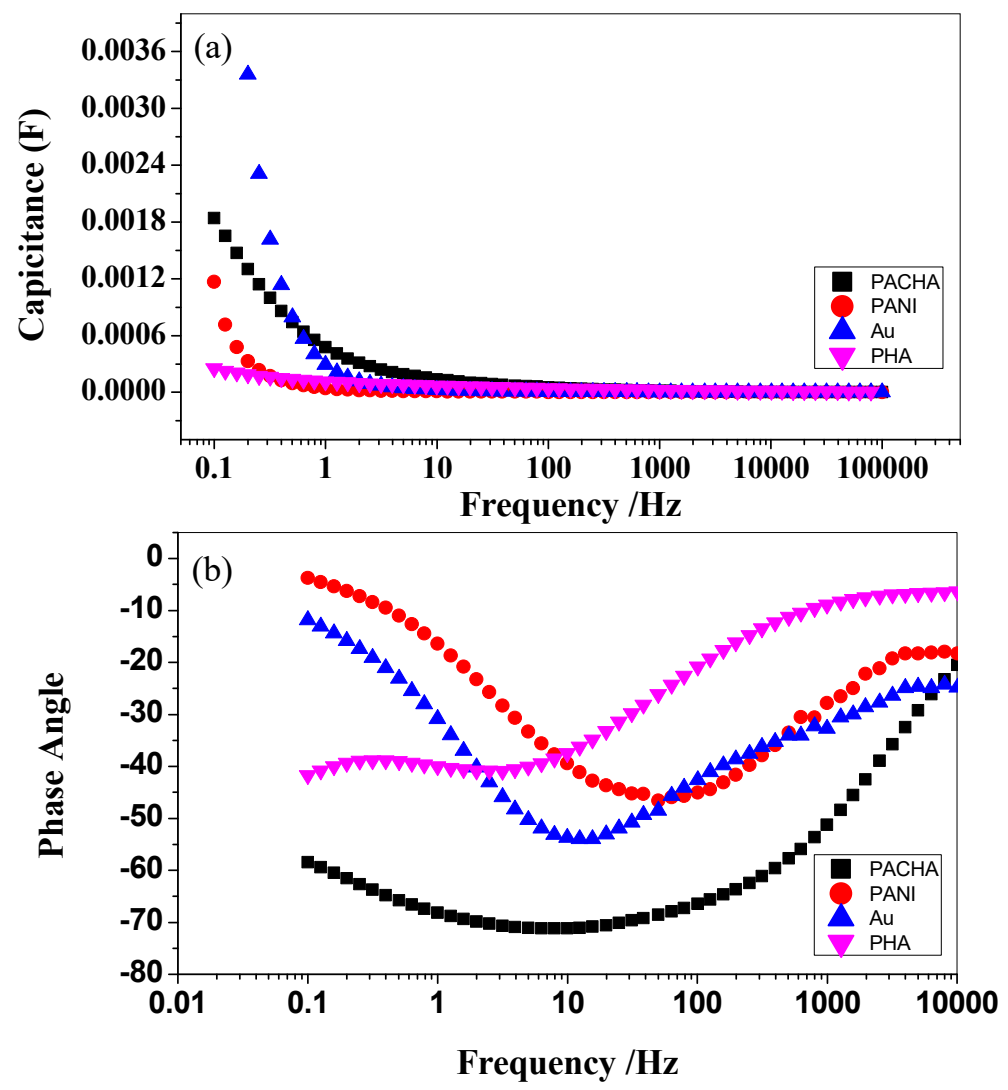

Figure 9. Bode plot for (a) capacitance and (b) phase angle in $1.4 \times 10^{-6} \mathrm{M} \mathrm{H}_{2} \mathrm{O}_{2}$. 


\section{Materials, Instruments, and Methods}

\subsection{Materials and Instrument}

Reagent grade aniline (Riedel-De Haën, Seelze, Germany) was distilled and then stored in nitrogen atmosphere. The reagent-grade 2-hydroxyaniline (ACROS), reagent-grade sulfuric acid (Riedel-De Haën, Seelze, Germany), $\mathrm{H}_{2} \mathrm{O}_{2}$ (analytical-grade), citric acid, and sodium citrate were used as received. Gamry Reference 3000 workstation (Warminster, PA, United States) was used for carrying out electrochemical measurements in a three-electrode assembly. Gold sheets of $0.5 \mathrm{~cm}^{2}$ area, gold wire, and a saturated calomel electrode were used as working, counter, and reference electrodes, respectively. LSV DPV EIS measurements were carried out in the frequency range of $0.1 \mathrm{~Hz}$ to $10^{5} \mathrm{~Hz}$ at $0.5 \mathrm{~V}$, with $5 \mathrm{mV}$ AC perturbation. Square wave voltammograms were recorded in the range of -0.2 to $0.5 \mathrm{~V}$ at $15 \mathrm{~Hz}$ with $4 \mathrm{mV}$ step size, $50 \mathrm{mV}$ pulse size and $0.06 \mathrm{~s}$ pulse time. Differential pulse voltammograms were recorded with $2 \mathrm{mV}$ step size, $50 \mathrm{mV}$ pulse size and $0.2 \mathrm{~s}$ pulse time in the potential range of -0.2 to $0.56 \mathrm{~V}$.

\subsection{Electrode Preparation}

The PANI, PHA, and PACHA were prepared by the electrooxidation of aniline, 2-hydroxyaniline, and its copolymer in $0.5 \mathrm{M}$ sulfuric acid solution at $50 \mathrm{mV} / \mathrm{s}$, while keeping the electrode potential range from $-0.2-0.85 \mathrm{~V}$ (for aniline and 2-hydroxyaniline) and -0.2-1.1 V (for the copolymer). The resulted CVs are shown in Figure 10.

The cyclic voltammograms (CVs) in Figure 10a display the growth of polyaniline film during the electrolysis of $20 \mathrm{mM}$ aniline in $0.5 \mathrm{M}$ sulfuric acid solution. There were three anodic peaks at $0.2 \mathrm{~V}, 0.48 \mathrm{~V}$, and $0.79 \mathrm{~V}$, while three cathodic peaks at $0.6 \mathrm{~V}, 0.39 \mathrm{~V}$, and $0.0 \mathrm{~V}$ were observed. The peak currents increase constantly with the increase in the number of potential cycles. This indicates that as the electrolysis proceeds, the film of polyaniline grows more rapidly. After electrolysis, a green film of polyaniline was formed on the working electrode.

Figure $10 \mathrm{~b}$ shows the cyclic voltammograms for electrolysis of $2 \mathrm{mM}$ 2-hydroxyaniline in $0.5 \mathrm{M}$ $\mathrm{H}_{2} \mathrm{SO}_{4}$ solution. Two anodic peaks can be observed, one at $0.64 \mathrm{~V}$, which is attributed to the oxidation of a hydroxyl group in the phenyl ring, and the other at $0.77 \mathrm{~V}$, which is due to the oxidation of an amino group in the phenyl ring of 2-hydroxyaniline. Oxidation currents at $0.64 \mathrm{~V}$ and $0.77 \mathrm{~V}$ decrease quickly with increase in the number of potential cycles, while a peak at $0.13 \mathrm{~V}$ developed, which is attributable to the oxidation of poly (2-hydroxyaniline). After 25 potential cycles, a thin golden film of poly (2-hydroxyaniline) was obtained on the working electrode. The slenderness of the film is due to the inhibited growth during the electrolysis, owing to the low conductance of poly (2-hydroxyaniline) [21].

Cyclic voltammograms for electrolysis of the solution containing a mixture of $2 \mathrm{mM}$ 2-hydroxyaniline and $20 \mathrm{mM}$ aniline in $0.5 \mathrm{M} \mathrm{H}_{2} \mathrm{SO}_{4}$ is given in Figure 10c. There are three anodic peaks and four cathodic peaks on the curves-i.e., changed from the curves in Figure 10a,b. The anodic peak at $0.66 \mathrm{~V}$ in Figure 10c is due to the oxidation of 2-hydroxyaniline, compared with that in Figure $10 \mathrm{~b}$. The formation of the three cathodic peaks indicates the formation of PACHA [21]. The oxidation peak at $0.24 \mathrm{~V}$ and reduction peak at $0.28 \mathrm{~V}$ and $0.5 \mathrm{~V}$ occurs on the cyclic voltammogram. This extra pair of redox peaks in Figure 10c is neither from the redox of 2-hydroxyaniline nor the polyaniline film, but rather is caused by the copolymer itself. Finally, a deep yellow film was formed on the working electrode. The fabricated electrodes were then used to check out their electrochemical behavior towards $\mathrm{H}_{2} \mathrm{O}_{2}$ oxidation. 


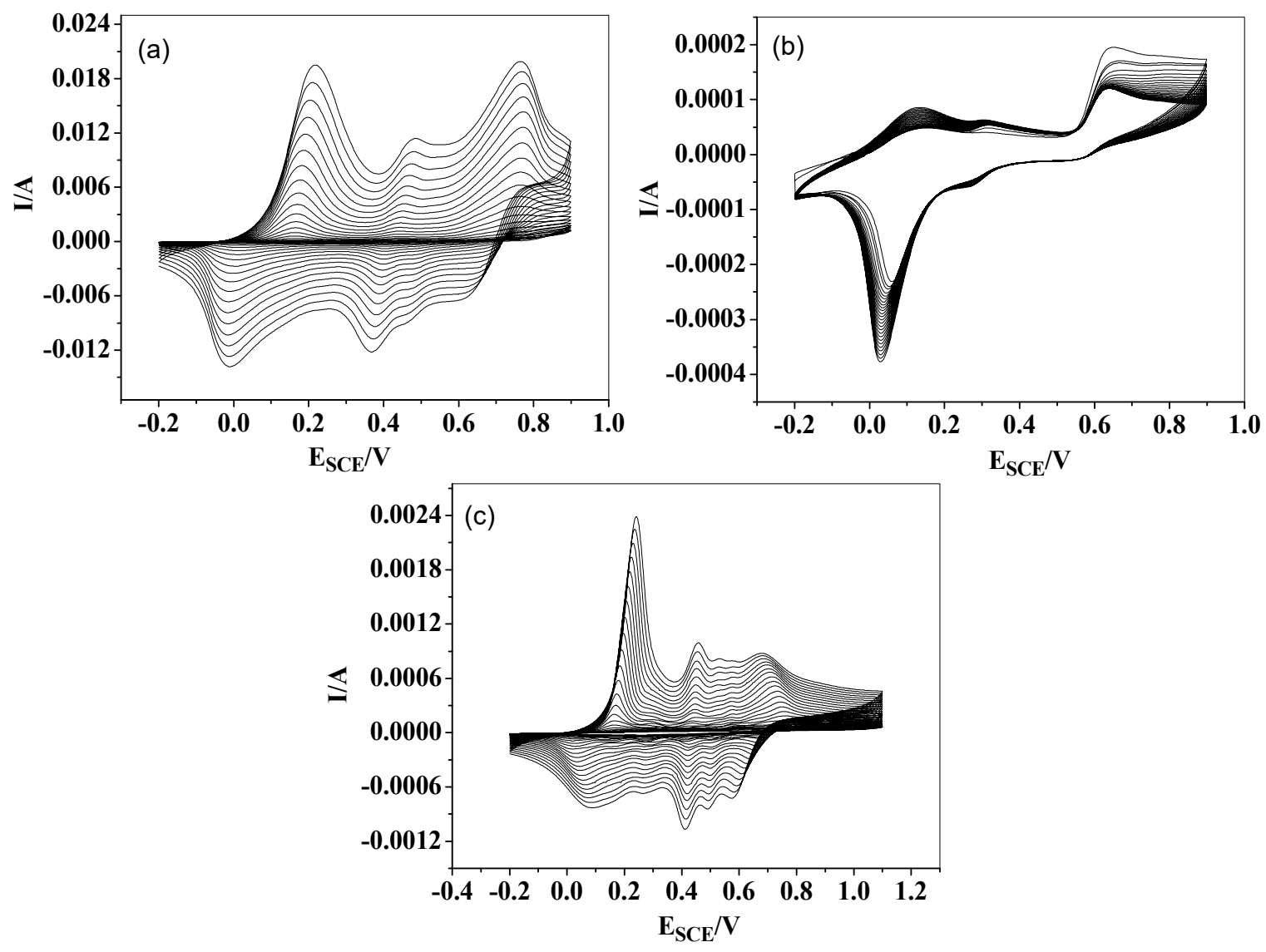

Figure 10. CV results recorded during the growth of (a) PANI, (b) PHA, and (c) PACHA film.

\section{Conclusions}

In conclusion, PACHA- and PANI-coated electrodes were successfully applied for the detection and determination of $\mathrm{H}_{2} \mathrm{O}_{2}$. The PACHA and PANI films can effectively support electron transfer, which makes them show a high electrochemical response towards $\mathrm{H}_{2} \mathrm{O}_{2}$. The fabricated electrodes show good sensitivity of $650 \mathrm{~A} / \mathrm{Mcm}^{2}$ (in the case of PACHA) and $464 \mathrm{~A} / \mathrm{Mcm}^{2}$ (in the case of PANI). Moreover, the LOD calculated from the calibration curve (CV current response to $\mathrm{H}_{2} \mathrm{O}_{2}$ concentration) was as low $1 \times 10^{-7} \mathrm{M}$, in the case of PACHA-coated electrodes, and $1.15 \times 10^{-7} \mathrm{M}$ in the case of PANI-coated electrodes. Considering the advantages, like good electrochemical behaviour, high sensitivity, good stability, and reproducibility, the materials show pronounced potential for the detection and determination of $\mathrm{H}_{2} \mathrm{O}_{2}$. Furthermore, this opens a new doorway for PACHA and PANI to be used in analytical devices. It also offers a way to detect $\mathrm{H}_{2} \mathrm{O}_{2}$ in many enzymes-catalyzed reactions, environmental samples, food, and clinical industries.

Supplementary Materials: The following are available online at http://www.mdpi.com/2073-4344/9/8/631/s1. Figure S1. CV of a PACHA-coated electrode in $1.4 \times 10^{-6} \mathrm{M} \mathrm{H}_{2} \mathrm{O}_{2}$ (a) before and (b) after 10 days. Figure S2. Calibration curve of current response of PACHA to $\mathrm{H}_{2} \mathrm{O}_{2}$ concentration ranges from $2 \times 10^{-7}$ to $1.2 \times 10^{-6} \mathrm{M}$. Figure S3. The current response of PACHA ti $\mathrm{H}_{2} \mathrm{O}_{2}$ concentration ranging from $2 \times 10^{-7}$ to $8 \times 10^{-7} \mathrm{M}$.

Author Contributions: A.u.H.A.S. conceptualized and supervised. A.I. performed experimental work. All the authors contributed in writing, editing, and analysis.

Funding: This research was funded by the Higher Education Commission Pakistan (project No. 20-1647 and 20-111/NRPU/R \& D/HEC). The APC was funded by the German Research Foundation and the Open Access Publication Funds of the Technische Universität Braunschweig.

Acknowledgments: We acknowledge support from the German Research Foundation and the Open Access Publication Funds of the Technische Universität Braunschweig. S.B. acknowledges support from the Alexander von Humboldt Foundation Germany. 
Conflicts of Interest: The authors declare no conflict of interest.

\section{References}

1. Cehoin, M.; Medic, A.; Scheideler, J.; Mielcke, J.; Ried, A.; Ompare, B.K.; Gotvajn, A.Z. Hydrodynamic cavitation in combination with the ozone, hydrogen peroxide and the UV-based advanced oxidation processes for the removal of natural organic matter from drinking water. Ultrason. Sonochem. 2017, 37, 394-404. [CrossRef]

2. Lu, Z.; Chen, G.; Siahrostami, S.; Chen, Z.; Liu, K.; Xie, J.; Liao, L.; Wu, T.; Lin, D.; Liu, Y.; et al. High efficiency oxygen reduction to hydrogen peroxide catalyzed by oxidized carbon material. Nat. Catal. 2018, 1, $240-245$. [CrossRef]

3. Sun, Y.; Luo, M.; Meng, X.; Xiang, J.; Wang, L.; Ren, Q.; Guo, S. Graphene/intermetallic PtPb nanoplates composites for boosting electrochemical detection of $\mathrm{H}_{2} \mathrm{O}_{2}$ released from cells. Anal. Chem. 2017, 89, 3761-3767. [CrossRef] [PubMed]

4. Ju, J.; Chen, W. In situ growth of surfactant-free gold nanoparticles on nitrogen-doped graphene quantum dots for electrochemical detection of hydrogen peroxide in biological environments. Anal. Chem. 2015, 87, 1903-1910. [CrossRef] [PubMed]

5. Gaschler, M.M.; Stockwell, B.R. Lipid peroxidation in cell death. Biochem. Biophys. Res. Commun. 2017, 482, 419-425. [CrossRef] [PubMed]

6. Rahimifard, M.; Nigjeh, M.N.; Baeeri, M.; Maqbool, F.; Abdollahi, M. Multiple protective mechanisms of alpha-lipoic acid in oxidation, apoptosis and inflammation against hydrogen peroxide induced toxicity in human lymphocytes. Mol. Cell. Biochem. 2015, 403, 179-186. [CrossRef] [PubMed]

7. Zhang, H.; Li, S.; Zhang, F.; Wang, M.; Lin, X.; Li, H. Simultaneous detection of hydroquinone and catechol on electrochemical-activated glassy carbon electrode by simple anodic and cathodic polarization. J. Solid State Electrochem. 2017, 21, 735-745. [CrossRef]

8. Yanga, X.; Kirscha, J.; Olsenb, E.V.; Fergus, J.W.; Simonian, A.L. Anti-fouling pedot: PSS modification on glassy carbon electrodes for continuous monitoring of tricresyl phosphate. Sens. Actuators B 2013, 177, 659-667. [CrossRef]

9. Silva, L.V.; Lopes, C.B.; Silva, W.C.; Paiva, Y.G.; SantosSilva, F.A.; Lima, P.R.; Kubota, L.T.; Goulart, M.O.F. Elevtropolymerization of ferulic acid on multi-walled carbon nanotubes modified glassy carbon electrode as a versatile platform for NADH, dopamine and epinephrine separate detection. Microchem. J. 2017, 133, 460-467. [CrossRef]

10. Sheng, Z.H.; Zheng, X.Q.; Xu, J.Y.; Bao, W.J.; Wang, F.B.; Xia, X.H. Electrochemical sensor based on nitrogen doped graphene: simultaneous determination of ascorbic acid, dopamine and uric acid. Biosens. Bioelectron. 2012, 34, 125-131. [CrossRef]

11. $\mathrm{Mu}, \mathrm{S}$. Catechol sensor using poly(aniline-co-o-aminophenol) as an electron transfer mediator. Biosens. Bioelectron. 2006, 21, 1237-1243. [CrossRef] [PubMed]

12. Qin, Q.; Bai, X.; Hua, Z. Electropolymerization of a conductive $\beta$-cyclodextrin polymer on reduced graphene oxide modified screen-printed electrode for simultaneous determination of ascorbic acid dopamine and uric acid. J. Electroanal. Chem. 2016, 782, 50-58. [CrossRef]

13. Shah, A.A.; Yasmeen, N.; Rahman, G.; Bilal, S. High electrocatalytic behaviour of Ni impregnated conducting polymer coated platinum and graphite electrodes for electrooxidation of methanol. Electrochim. Acta 2017, 224, 468-474. [CrossRef]

14. Luo, J.; Ma, Q.; Gu, H.; Zhen, Y.; Liu, X. Three-dimensional graphene-polyaniline hybrid hollow spheres by layer-by-layer assembly for application in supercapacitor. Electrochim. Acta 2015, 173, 184-192. [CrossRef]

15. Ullah, H.; Shah, A.A.; Bilal, S.; Ayub, K. DFT study of polyaniline NH3, $\mathrm{CO}_{2}$, and CO gas sensors: Comparison with recent experimental data. J. Phys. Chem. C 2013, 117, 23701-23711. [CrossRef]

16. Debnath, S.; Ballav, N.; Nyoni, H.; Maity, A.; Pillay, K. Optimization and mechanism elucidation of the catalytic photo-degradation of the dyes eosin yellow (EY) and naphthol blue black (NBB) by a polyaniline-coated titanium dioxide nanocomposite. Appl. Catal. B 2015, 163, 330-342. [CrossRef]

17. Ullah, R.; Bilal, S.; Ali, K.; Shah, A.A. Synthesis and characterization of polyaniline doped with Cu II chloride by inverse emulsion polymerization. Synth. Met. 2014, 198, 113-117. [CrossRef] 
18. Shah, A.A.; Yasmeen, N.; Rahman, G.; Mehmood, M.; Bilal, S. Electrooxidation of methanol at PANI/POAP bilayered structure modified platinum and graphite electrode. Electrochim. Acta 2016, 188,367-377. [CrossRef]

19. Chasta, H.R.; Goyal, R.N. Molecularly imprinted sensor based on 0 -aminophenol for the selective determination of norepinephrine in pharmaceutical and biological samples. Talanta 2014, 125, 167-173. [CrossRef]

20. Shah, A.A.; Holze, R. Spectroelectrochemistry of aniline-o-aminophenol copolymers. Electrochim. Acta 2006, 52, 1374-1382. [CrossRef]

21. $\mathrm{Mu}, \mathrm{S}$. Electrochemical copolymerization of aniline and o-aminophenol. Synth. Met. 2004, 143, $259-268$. [CrossRef]

22. Wang, M.; Wang, X.; Chen, M.; Yang, Z.; Dong, C. Nanostructured electrocatalytic materials and porous electrodes for direct methanol fuel cells. Chin. J. Catal. 2016, 37, 1037-1048. [CrossRef]

23. Mascaro, L.H.; Berton, A.N.; Micaroni, L. Electrochemical synthesis of polyaniline/poly-o-aminophenol copolymers in chloride medium. Int. J. Electrochem. 2011, 2011, 1-8. [CrossRef]

24. Yang, Y.; Mu, S. Poly(aniline-co-o-aminophenol): In situ Electrochemical-ESR Measurements in Aqueous Solutions and as a Probe of Radical Scavengers. J. Phys. Chem. C 2011, 115, 18721-18728. [CrossRef]

25. Mu, S.; Chen, C. Electron Spin Resonance Spectroscopic Studies on the Radical Scavenging Capacities of Catechin and Pyrogallol. J. Phys. Chem. C 2012, 116, 3065-3070. [CrossRef]

26. Poly, S.M. (aniline-co-o-aminophenol) nanostructured network: Electrochemical controllable synthesis and electrocatalysis. Electrochim. Acta 2006, 51, 3434-3440. [CrossRef]

27. Chen, C.; Sun, C.; Gao, Y. Amperometric sensor for hydrogen peroxide based on poly(aniline-co-p-aminophenol). Electrochem. Commun. 2009, 11, 450-453. [CrossRef]

28. Kim, H.; Choi, S.; Oh, S.; Woo, J.; Kim, I.K. Horseradish peroxidase immobilized on poly(thiophene-2-aminophenol-3-thiopheneacetic acid) film electrode with au nanoparticle-fabrication and evaluation as hydrogen peroxide sensor. J. Nanosci. Nanotechnol. 2008, 8, 4962-4967. [CrossRef]

29. Yang, Y.; Mu, S. Determination of hydrogen peroxide using amperometric sensor of polyaniline doped with ferrocenesulfonic acid. Biosens. Bioelectron. 2005, 21, 74-78. [CrossRef]

30. Shrivastava, A.; Gupta, V.B. Methods for the determination of limit of detection and limit and quantification of the analytical methods. Chron. Young Sci. 2011, 2, 21-25. [CrossRef]

31. Žabčíková, S.; Mikysek, T.L.L.Č.; Sýs, M. Electrochemical study and determination of all-trans-retinol at carbon paste electrode modified by a surfactant. Food. Technol. Biotechnol. 2018, 56, 337-343. [CrossRef] [PubMed]

32. Guerreiro, G.V.; Zaitouna, A.J.; Lai, R.Y. Characterization of an electrochemical mercury sensor using alternating current, cyclic, square wave and differential pulse voltammetry. Anal. Chim. Acta 2014, 810, 79-85. [CrossRef] [PubMed]

33. Levar, C.E.; Chan, C.H.; Mehta-Kolte, M.G.; Bond, D.R. An inner membrane cytochrome required only for reduction of high redox potential extracellular electron acceptors. ASM 2014, 5, 1-9. [CrossRef] [PubMed]

34. Yusoff, N.; Rameshkumar, P.; Mehmood, M.S.; Pandikumar, A.; Wah, L.H.; Ming, H.N. Ternary nanohybrid of reduced graphene oxide- nafion@silver nanoparticles for boosting the sensor performance in non-enzymatic amperometric detection of hydrogen peroxide. Biosens. Bioelectron. 2017, 87, 1020-1028. [CrossRef] [PubMed]

35. Ensafi, A.A.; Rezaloo, F.; Rezaei, B. Electrochemical sensor based on porous silicon/silver nanocomposite for the determination of hydrogen peroxide. Sens. Actuators B 2016, 231, 239-244. [CrossRef]

36. Zhang, R.; Chen, W. Recent advances in graphene-based nanomaterials for fabricating electrochemical hydrogen peroxide sensors. Biosens. Bioelectron. 2017, 89, 249-268. [CrossRef] [PubMed]

37. Amiri, M.; Nouhi, S.; Azizian-Kalandaragh, Y. Facilesynthesis of silver nanostructures by using various deposition potential and time: A nonenzymetic sensor for hydrogen peroxide. Mater. Chem. Phys. 2015, 155, 129-135. [CrossRef]

38. Ahmad, K.; Mohammad, A.; Mobin, S.M. Hydrothermally grown $\alpha$-MnO2 nanorods as highly efficient low cost counter-electrode material for dye-sensitized solar cells and electrochemical sensing applications. Electrochim. Acta 2017, 252, 549-557. [CrossRef]

39. Wang, Y.; Wang, Z.; Rui, Y.; Li, M. Horseradish peroxidase immobilization on carbon nanodots/CoFe layered double hydroxides: Direct electrochemistry and hydrogen peroxide sensing. Biosens. Bioelectron. 2015, 64, 57-62. [CrossRef] 
40. Chen, D.; Wang, G.; Lua, W.; Zhang, H.; Li, J.H. Photoelectrochemical study of organic-inorganic hybrid thin films via electrostatic layer-by-layer assembly. Electrochem. Commun. 2007, 9, 2151-2156. [CrossRef]

41. Katz, E.; Willner, I. Probing biomolecular interactions at conductive and semiconductive surfaces by impedance spectroscopy: routes to impedimetric immunosensors, DNA-sensors, and enzyme Biosensors. Electroanalysis 2003, 15, 913-947. [CrossRef]

42. Apodaca, D.C.; Pernites, R.B.; Ponnapati, R.; Mundo, F.R.D.; Advincula, R.C. electropolymerized molecularly imprinted polymer film: EIS sensing of bisphenol. Macromolecules 2011, 44, 6669-6682. [CrossRef]

43. Jeng, K.T.; Chian, C.C.; Hsu, N.Y.; Huang, W.M.; Chiou, S.D.; Lin, S.H. Fabrication and impedance studies of DMFC anode incorporated with CNT-supported high-metal-content electrocatalyst. J. Power Sources 2007, 164, 33-41. [CrossRef]

(C) 2019 by the authors. Licensee MDPI, Basel, Switzerland. This article is an open access article distributed under the terms and conditions of the Creative Commons Attribution (CC BY) license (http://creativecommons.org/licenses/by/4.0/). 